\begin{tabular}{|c|c|}
\hline $\begin{array}{l}\text { Chemistry of } \\
\text { Metals and Alloys }\end{array}$ & 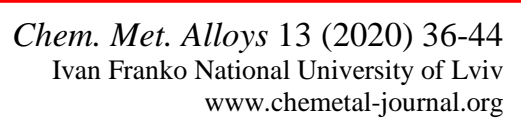 \\
\hline
\end{tabular}

\title{
Structural defects of rare-earth disilicides and digermanides
}

\author{
Svitlana PUKAS ${ }^{1 *}$, Roman GLADYSHEVSKII $^{1}$ \\ ${ }^{1}$ Department of Inorganic Chemistry, Ivan Franko National University of Lviv, \\ Kyryla i Mefodiya St. 6, 79005 Lviv, Ukraine \\ * Corresponding author.Tel.: +380-32-2394506; e-mail: svitlana.pukas@lnu.edu.ua \\ Received May 25, 2020; accepted July 3, 2020; available on-line November 1, 2020 \\ https://doi.org/10.30970/cma13.0403
}

\begin{abstract}
Based on literature data and own experimental data the crystal structures of (defect) binary disilicides and digermanides of rare-earth metals $(R)$ have been reviewed and discussed. In each of the binary systems $R-\{\mathrm{Si}, \mathrm{Ge}\}$ up to six compounds of variable composition $R_{\mathrm{Si}_{2-x}}$ or $R \mathrm{Ge}_{2-x}(x=\mathbf{0 - 0 . 5})$ are known. At certain compositions ordering of vacancies with formation of superstructures is observed. The electronic factor has a significant impact on the formation of a particular type of structure and it is shown that an essential criterion for the formation of stoichiometric and off-stoichiometric disilicides (digermanides) of rare-earth metals is the valence electron concentration per $p$-element atom $\left(\mathrm{VEC}_{\mathrm{A}}\right)$, which should not exceed 8.3. The required value of $\mathrm{VEC}_{\mathrm{A}}$ may be achieved by $\mathrm{Si}(\mathrm{Ge})$ vacancies, heterovalent substitution by $\mathrm{Al}$ or Ga atoms, or intergrowth with other structural segments.
\end{abstract}

Rare-earth metal / Silicide / Germanide / Crystal structure / Vacancy derivative / Structure series / Valence electron concentration

\section{Introduction}

For all the binary systems $R-\{\mathrm{Si}, \mathrm{Ge}\}$, where $R$ is a rare-earth metal, with the exception of the $\{\mathrm{Eu}, \mathrm{Tm}, \mathrm{Lu}\}-\mathrm{Si}$ systems, phase diagrams have been constructed, and for most of the compounds formed in these systems, the crystal structures are known [1-3]. However, more detailed studies are needed for disilicides and digermanides, where from 3 to 11 structure types have been reported $[4,5]$. In the $R-\mathrm{Si}$ systems, where $R$ is a light rare-earth element, a full row of $R \mathrm{Si}_{2}$ compounds with tetragonal $\alpha$-ThSi $i_{2}$-type structures is observed at high temperatures, while the orthorhombic $\alpha$-GdSi $i_{2}$-type is adopted at lower temperatures (exception Eu) (Table 1). At high temperatures the heavy rare-earth elements form a full row of isotypic compounds of composition $R \mathrm{Si}_{1.67}$ with the hexagonal structure type $\mathrm{AlB}_{2}$ [6]. In the $R-\mathrm{Ge}$ systems, the early rare-earth metals also form a full row (exception Eu) of compounds with the structure type $\alpha-\mathrm{ThSi}_{2}$ at high temperatures [7], but not at the stoichiometry $1: 2$. The structures of the lowtemperature modifications belong to orthorhombic derivatives of the $\alpha-\mathrm{ThSi}_{2}$ type (Table 2). Similarly to the $R-\mathrm{Si}$ systems, in the $R-\mathrm{Ge}$ systems, representatives of the late rare-earth metals form compounds that crystallize with structures of the $\mathrm{AlB}_{2}$ type, or closely related types in the case of $\mathrm{Tm}$ and $\mathrm{Yb}$.

Consequently, the most common structure types among rare-earth disilicides and digermanides are
$\mathrm{AlB}_{2}$ (10 silicides and 8 germanides), $\alpha-\mathrm{ThSi}_{2}$ (8 and 8 ), and $\alpha-\mathrm{GdSi}_{2}$ (9 and 4). Structures of the $\mathrm{AlB}_{2}$ and $\alpha-\mathrm{ThSi}_{2}$ types and their defective derivatives form in the concentration range $36.4-40.0$ at. $\%$ R, i.e. the composition of the compounds differs from the ideal $R \mathrm{Si}_{2}$ or $R \mathrm{Ge}_{2}$ stoichiometries and can be described by the formulas $R \mathrm{Si}_{2-x}$ or $R \mathrm{Ge}_{2-x}$, where $x=0.25-0.50$, or $R_{4} \mathrm{Ge}_{7}, R_{3} \mathrm{Si}_{5}\left(R_{3} \mathrm{Ge}_{5}\right), R_{2} \mathrm{Ge}_{3}$ when $x=1 / 4,1 / 3,1 / 2$, respectively, and show partial $\mathrm{Si}$ or $\mathrm{Ge}$ defects. Defective derivatives of the hexagonal structure type $\mathrm{AlB}_{2}$ with an ordered arrangement of vacancies that have been reported for rare-earth silicides and germanides are the hexagonal structure type $\mathrm{Th}_{3} \mathrm{Pd}_{5}$ [8] (16.7\% vacancies) and the monoclinic structure type $\mathrm{Tm}_{2} \mathrm{Ge}_{3}$ [9] (25\%) (Fig. 1). The representatives of the orthorhombic structure types $\mathrm{ErSi}_{1.67}$ [10] (16.7\%) and $\mathrm{Er}_{3} \mathrm{Si}_{5-x}$ [11] (20.7\%) exhibit partly ordered vacancies. Lowering of the temperature often promotes the ordering of vacancies. Defective derivatives of the tetragonal structure type $\alpha-\mathrm{ThSi}_{2}$ with ordered arrangements of vacancies are the orthorhombic types $\mathrm{Nd}_{4} \mathrm{Ge}_{7}$ [12] (12.5\% vacancies) and $\mathrm{Y}_{3} \mathrm{Ge}_{5}$ [13] (16.7\%) (Fig. 2), as well as the types $\mathrm{Gd}_{17} \mathrm{Ge}_{29}$ [13] (14.7\%), $\mathrm{Ho}_{14} \mathrm{Ge}_{23}$ [13] (17.9\%), $\mathrm{Dy}_{11} \mathrm{Ge}_{18}$ [13] (18.2\%), and $\mathrm{Ce}_{9} \mathrm{Ge}_{14}$ [14] (22.3\%) with large unit cells. For off-stoichiometric compositions the orthorhombic structure type $\alpha-\mathrm{GdSi}_{2}$ [15] exhibits partial ordering of vacancies.

The aim of the present work was to study the reasons for structural defects in rare-earth disilicides and digermanides. 
Table 1 Structure type, type and temperature (in K) of formation $(L-$ from the melt, $P$ - peritectic, $P D$ - peritectoid, $T$ - polymorphic transformation) of binary compounds $R \mathrm{Si}_{2-x}$.

\begin{tabular}{|c|c|c|c|c|c|c|c|c|}
\hline$x$ & $\begin{array}{c}\text { Structure } \\
\text { type }\end{array}$ & $\mathrm{La}$ & $\mathrm{Ce}$ & $\operatorname{Pr}$ & $\mathrm{Nd}$ & $\mathrm{Sm}$ & $\mathrm{Eu}$ & $\mathrm{Gd}$ \\
\hline$\sim 0^{1}$ & $\alpha-\mathrm{ThSi}_{2}$ & $\begin{array}{c}\mathrm{LaSi}_{2} \\
(P, \sim 1875)\end{array}$ & $\begin{array}{c}\mathrm{CeSi}_{2} \\
(L, 1893)\end{array}$ & \multirow{2}{*}{$\begin{array}{c}\mathrm{PrSi}_{2} \\
(L, 1985) \\
\mathrm{PrSi}_{2} \\
(T, 430)\end{array}$} & \multirow{2}{*}{$\begin{array}{c}\mathrm{NdSi}_{2} \\
(L, 2030) \\
\mathrm{NdSi}_{2} \\
(T, 420)\end{array}$} & \multirow{2}{*}{$\begin{array}{c}\mathrm{SmSi}_{2} \\
(L, 2113) \\
\mathrm{SmSi}_{2} \\
(T, 653)\end{array}$} & $\begin{array}{c}\mathrm{EuSi}_{2} \\
(\ldots)\end{array}$ & \multirow{2}{*}{$\begin{array}{c}\mathrm{GdSi}_{2} \\
(L, 2373) \\
\mathrm{GdSi}_{2} \\
(T, 673)\end{array}$} \\
\hline$\sim 0.3$ & $\alpha-\mathrm{GdSi}_{2}$ & $\begin{array}{c}\mathrm{LaSi}_{1.67} \\
(L, 2003)\end{array}$ & $\begin{array}{c}\mathrm{CeSi}_{1.67} \\
(P, 1833)\end{array}$ & & & & & \\
\hline \multirow{2}{*}{$\sim 0.5$} & $\ldots$ & & & & \multirow{2}{*}{$\begin{array}{c}\mathrm{NdSi}_{1.5} \\
(P D, 1780) \\
\mathrm{NdSi}_{1.5} \\
(T, 800)\end{array}$} & & & \multirow{2}{*}{$\begin{array}{c}\mathrm{GdSi}_{1.5} \\
(P D, 2073) \\
\mathrm{GdSi}_{1.5} \\
(T, 1393)\end{array}$} \\
\hline & $\mathrm{AlB}_{2}$ & & & & & $\begin{array}{c}\mathrm{SmSi}_{1.67} \\
(P D, 1853)\end{array}$ & & \\
\hline
\end{tabular}

\begin{tabular}{|c|c|c|c|c|c|c|c|c|}
\hline$x$ & $\begin{array}{c}\text { Structure } \\
\text { type }\end{array}$ & $\mathrm{Tb}$ & Dy & Ho & Er & $\mathrm{Tm}$ & $\mathrm{Yb}$ & $\mathrm{Lu}$ \\
\hline \multirow{2}{*}{$\sim 0.2$} & $\alpha-\mathrm{ThSi}_{2}$ & & $\begin{array}{c}\mathrm{DySi}_{1.75} \\
(P, 1703)\end{array}$ & & & & & \\
\hline & $\alpha-\mathrm{GdSi}_{2}$ & $\begin{array}{c}\mathrm{TbSi}_{2} \\
(P, 1790)\end{array}$ & $\begin{array}{l}\text { DySi }_{1.75} \\
(T, 813)\end{array}$ & $\begin{array}{l}\mathrm{HoSi}_{1.82} \\
(P, 793)\end{array}$ & & & & \\
\hline \multirow{4}{*}{$\sim 0.3$} & $\mathrm{AlB}_{2}$ & $\begin{array}{c}\mathrm{TbSi}_{1.67} \\
(P, 1911)\end{array}$ & \multirow{2}{*}{$\begin{array}{c}\text { DySi }_{1.6} \\
(P, 1908) \\
\text { DySi }_{1.6} \\
(T, 1033)\end{array}$} & \multirow{2}{*}{$\begin{array}{c}\mathrm{HoSi}_{1.67} \\
(P, 1893) \\
\mathrm{HoSi}_{1.67} \\
(T, 1073)\end{array}$} & \multirow{2}{*}{$\begin{array}{c}\operatorname{ErSi}_{1.67} \\
(P, 1893) \\
\operatorname{ErSi}_{1.67} \\
(T, 1078)\end{array}$} & $\begin{array}{c}\operatorname{TmSi}_{1.67} \\
(\ldots)\end{array}$ & $\begin{array}{c}\mathrm{YbSi}_{1.8} \\
(P, 1698)\end{array}$ & $\begin{array}{c}\mathrm{LuSi}_{1.67} \\
(\ldots)\end{array}$ \\
\hline & $\ldots$ & & & & & & & \\
\hline & $\mathrm{ErSi}_{1.67}$ & & & & $\begin{array}{l}\mathrm{ErSi}_{1.67} \\
(?, 15)\end{array}$ & & & \\
\hline & $\mathrm{Th}_{3} \mathrm{Pd}_{5}$ & & & & & & $\begin{array}{c}\mathrm{Yb}_{3} \mathrm{Si}_{5} \\
(P D, 1238)\end{array}$ & \\
\hline
\end{tabular}

compositions near 1:2 need to be confirmed

\section{Relationship between structural defects and valence electron concentration}

Based on literature data and own experimental investigations carried out in several systems [16] it was found that the main criterion for the formation of rare-earth silicides and germanides with the structure types $\mathrm{AlB}_{2}, \alpha-\mathrm{ThSi}_{2}$ and vacancy derivatives of these is the valence electron concentration. For a (hypothetical) compound $R^{3+} \mathrm{Si}_{2}$ or $R^{3+} \mathrm{Ge}_{2}$ ( $\mathrm{Si}$ and $\mathrm{Ge}$ are located on the Zintl line), the number of valence electrons per $p$-element atom $(\mathrm{A}=$ anion $)$, by analogy with ionocovalent compounds [17], can be calculated by the formula:

$$
\mathrm{VEC}_{\mathrm{A}}=[(1 \times 3 \overline{\mathrm{e}}(R)+2 \times 4 \overline{\mathrm{e}}(\mathrm{A})) / 2]+\mathrm{AA}=5.5+\mathrm{AA} .
$$

After having received 3 electrons from each rare-earth atom, to fill the outer electron shell (octet), each $\mathrm{Si}$ or Ge atom still needs 2.5 additional electrons, which it may receive by forming $n$ homoatomic $\mathrm{A}-\mathrm{A}$ bonds (AA). In the defect-free structures of the $\mathrm{AlB}_{2}$ and $\alpha-\mathrm{ThSi}_{2}$ types, the $\mathrm{Si}$ or $\mathrm{Ge}$ atoms form flat nets or frameworks, where each atom participates in three homoatomic bonds. It follows from the formula above that $\mathrm{VEC}_{\mathrm{A}}=8.5$, i.e. part of the valence electrons are not localized in bonds.

In fact, for the compounds with structure types $\mathrm{AlB}_{2}, \alpha-\mathrm{ThSi}_{2}$ and derivatives considered here, the number of $\mathrm{Si}-\mathrm{Si}$ or $\mathrm{Ge}-\mathrm{Ge}$ bonds per $p$-element atom is slightly less than three, due to partial vacancies. For the deficient structures of $R \mathrm{Si}_{2-x}$ or $R \mathrm{Ge}_{2-x}$, the average number of $\mathrm{A}-\mathrm{A}$ bonds per $\mathrm{Si}$ or Ge atom (AA) can be calculated by the formula:

$$
\mathrm{AA}=\frac{6(1-\mathrm{x})}{2-\mathrm{x}} \text {. }
$$

The valence electron concentration per anion will be equal to:

$$
\mathrm{VEC}_{\mathrm{A}}=4+\frac{3}{2-\mathrm{x}}+\frac{6(1-\mathrm{x})}{2-\mathrm{x}}=\frac{17-10 \mathrm{x}}{2-\mathrm{x}} .
$$

In Table $3 \mathrm{VEC}_{\mathrm{A}}$ values for particular compositions are given. As can be seen, at the composition $R^{3+} \mathrm{Si}_{1.5}$ or $R^{3+} \mathrm{Ge}_{1.5}\left(R_{2} \mathrm{Ge}_{3}\right)$ the compound can be assimilated to a polyanionic valence compound [17].

In the systems $R-\mathrm{Si}$ and $R-\mathrm{Ge}$ the structure types $\mathrm{AlB}_{2}, \alpha-\mathrm{ThSi}_{2}$ and derivatives are formed at a valence electron concentration per $\mathrm{Si}$ or $\mathrm{Ge}$ atom of $\mathrm{VEC}_{\mathrm{A}}=8-8.3$. This value does not correspond to the ideal stoichiometry $1: 2$, but is achieved thanks to vacancies on the $\mathrm{Si}$ or $\mathrm{Ge}$ sites. For the compounds considered here there is a clear tendency toward higher numbers of vacancies in the structure type $\mathrm{AlB}_{2}$, compared to the structure type $\alpha-\mathrm{ThSi}_{2}$, which may be due to the configuration of the anion sublattices (two-dimensional nets in the former, a three-dimensional framework in the latter). $\mathrm{VEC}_{\mathrm{A}}$ values smaller than 8 are unlikely. 
Replacement of part of the $\mathrm{Si}$ or Ge atoms with four valence electrons by $\mathrm{Al}$ or $\mathrm{Ga}$ atoms with three valence electrons will lead to a decrease of the $\mathrm{VEC}_{\mathrm{A}}$ values. However, this heterovalent substitution is usually accompanied by the inclusion of additional small atoms, which in turn increases the value of $\mathrm{VEC}_{\mathrm{A}}$. For solid solutions based on binary compounds and truly ternary compounds $R \mathrm{Si}_{2-x-y} \mathrm{Al}_{y} \square_{x}$ with the structure types $\mathrm{AlB}_{2}, \alpha-\mathrm{ThSi}_{2}$ and derivatives, the valence electron concentration per anion can be represented by the formula:

$$
\begin{aligned}
\mathrm{VEC}_{\mathrm{A}} & =\mathrm{C}+\frac{3}{2-\mathrm{x}}+\frac{6(1-\mathrm{x})}{2-\mathrm{x}}=\mathrm{C}+\frac{3(3-2 \mathrm{x})}{2-\mathrm{x}}, \\
\mathrm{C} & =\frac{[\mathrm{Al}(\mathrm{Ga})] \times 3+[\mathrm{Si}(\mathrm{Ge})] \times 4}{[\mathrm{Al}(\mathrm{Ga})]+[\mathrm{Si}(\mathrm{Ge})]},
\end{aligned}
$$

where $[\mathrm{Al}(\mathrm{Ga})]$ and $[\mathrm{Si}(\mathrm{Ge})]$ are the number of atoms of the corresponding elements in one formula unit.

Table 2 Structure type, type and temperature $(\mathrm{K})$ of formation $(L-$ from the melt, $P$ - peritectic,

\begin{tabular}{|c|c|c|c|c|c|c|c|c|}
\hline$x$ & $\begin{array}{c}\text { Structure } \\
\text { type }\end{array}$ & $\mathrm{La}$ & $\mathrm{Ce}$ & $\operatorname{Pr}$ & $\mathrm{Nd}$ & $\mathrm{Sm}$ & $\mathrm{Eu}$ & $\mathrm{Gd}$ \\
\hline$\sim 0$ & $\mathrm{EuGe}_{2}$ & & & & & & $\begin{array}{c}\mathrm{EuGe}_{2} \\
(\ldots)\end{array}$ & \\
\hline$\sim 0.1$ & $\begin{array}{c}\mathrm{TbGe}_{2} \\
\left(\mathrm{PrGe}_{1.91}\right)\end{array}$ & & & $\begin{array}{c}\operatorname{PrGe}_{1.91} \\
(\ldots) \\
\end{array}$ & & & & $\begin{array}{c}\mathrm{GdGe}_{1.97} \\
(\ldots)\end{array}$ \\
\hline \multirow{5}{*}{$\sim 0.3$} & $\alpha-\mathrm{ThSi}_{2}$ & $\begin{array}{c}\mathrm{LaGe}_{1.6} \\
(L, 1500)\end{array}$ & $\begin{array}{l}\mathrm{CeGe}_{1.67} \\
(L, 1513)\end{array}$ & $\begin{array}{c}\operatorname{PrGe}_{1.6} \\
(L, 1506)\end{array}$ & $\begin{array}{c}\mathrm{NdGe}_{1.6} \\
(L, 1487)\end{array}$ & $\begin{array}{c}\mathrm{SmGe}_{2} \\
(P D, 760)\end{array}$ & & $\begin{array}{c}\mathrm{GdGe}_{1.63} \\
(P D, 808)\end{array}$ \\
\hline & $\mathrm{Nd}_{4} \mathrm{Ge}_{7}$ & $\begin{array}{c}\mathrm{La}_{4} \mathrm{Ge}_{7} \\
(\ldots)\end{array}$ & $\begin{array}{c}\mathrm{Ce}_{4} \mathrm{Ge}_{7} \\
(\ldots)\end{array}$ & $\begin{array}{c}\mathrm{Pr}_{4} \mathrm{Ge}_{7} \\
(\ldots)\end{array}$ & $\begin{array}{c}\mathrm{Nd}_{4} \mathrm{Ge}_{7} \\
(\ldots)\end{array}$ & $\begin{array}{c}\mathrm{Sm}_{4} \mathrm{Ge}_{7} \\
(\ldots)\end{array}$ & & \\
\hline & $\mathrm{Y}_{3} \mathrm{Ge}_{5}$ & $\begin{array}{c}\mathrm{La}_{3} \mathrm{Ge}_{5} \\
(\ldots)\end{array}$ & $\begin{array}{c}\mathrm{Ce}_{3} \mathrm{Ge}_{5} \\
(T, 560)\end{array}$ & $\begin{array}{c}\mathrm{Pr}_{3} \mathrm{Ge}_{5} \\
(T, 615)\end{array}$ & $\begin{array}{c}\mathrm{Nd}_{3} \mathrm{Ge}_{5} \\
(\ldots)\end{array}$ & $\begin{array}{c}\mathrm{Sm}_{3} \mathrm{Ge}_{5} \\
(\ldots)\end{array}$ & & $\begin{array}{l}\mathrm{Gd}_{3} \mathrm{Ge}_{5} \\
(T, 600)\end{array}$ \\
\hline & $\alpha-\mathrm{GdSi}_{2}$ & $\begin{array}{l}\mathrm{LaGe}_{1.6} \\
(T, 455)\end{array}$ & $\begin{array}{c}\mathrm{CeGe}_{1.75} \\
(\ldots)\end{array}$ & $\begin{array}{c}\mathrm{PrGe}_{2} \\
(P D, 615)\end{array}$ & $\begin{array}{l}\mathrm{NdGe}_{1.6} \\
(T, 680)\end{array}$ & & & \\
\hline & $\mathrm{YGe}_{1.7}$ & & & $\begin{array}{c}\operatorname{PrGe}_{1.6} \\
(\ldots)\end{array}$ & & & & \\
\hline$\sim 0.5$ & $\mathrm{AlB}_{2}$ & & & & & $\begin{array}{c}\mathrm{SmGe}_{1.5} \\
(P, 1355)\end{array}$ & & $\begin{array}{c}\mathrm{GdGe}_{1.56} \\
(T, 833)\end{array}$ \\
\hline
\end{tabular}
$P D$ - peritectoid, $T$ - polymorphic) of binary compounds $R \mathrm{Ge}_{2-x}$.

\begin{tabular}{|c|c|c|c|c|c|c|c|c|}
\hline$x$ & $\begin{array}{c}\text { Structure } \\
\text { type }\end{array}$ & $\mathrm{Tb}$ & Dy & Ho & $\mathrm{Er}$ & $\mathrm{Tm}$ & $\mathrm{Yb}$ & $\mathrm{Lu}$ \\
\hline$\sim 0$ & $\begin{array}{c}\mathrm{ErGe}_{2.16} \\
\mathrm{ZrSi}_{2}\end{array}$ & & & & $\begin{array}{c}\mathrm{ErGe}_{2.16} \\
(\ldots)\end{array}$ & $\begin{array}{l}\mathrm{Tm}_{0.9} \mathrm{Ge}_{2} \\
(P, 1158)\end{array}$ & & $\begin{array}{c}\mathrm{LuGe}_{1.8} \\
(P, 1338)\end{array}$ \\
\hline \multirow{2}{*}{$\sim 0.1$} & $\begin{array}{c}\mathrm{TbGe}_{2} \\
\left(\mathrm{PrGe}_{1.91}\right)\end{array}$ & $\begin{array}{c}\mathrm{TbGe}_{2} \\
(P, 1213)\end{array}$ & $\begin{array}{c}\mathrm{DyGe}_{1.90} \\
(\ldots)\end{array}$ & & & & & \\
\hline & $\mathrm{TmGe}_{1.9}$ & & & & & $\begin{array}{c}\mathrm{TmGe}_{1.9} \\
(P, 1295)\end{array}$ & & \\
\hline$\sim 0.2$ & $\begin{array}{l}\mathrm{DyGe}_{1.85} \\
\mathrm{YGe}_{1.82}\end{array}$ & & $\begin{array}{l}\text { DyGe }_{1.85} \\
(P, 1240)\end{array}$ & $\begin{array}{l}\mathrm{HoGe}_{1.85} \\
(P, 1273) \\
\end{array}$ & $\begin{array}{c}\mathrm{ErGe}_{1.83} \\
(T, 1180)\end{array}$ & $\begin{array}{l}\mathrm{TmGe}_{1.83} \\
(P, 1313)\end{array}$ & & \\
\hline \multirow{3}{*}{$\sim 0.3$} & $\alpha-\mathrm{ThSi}_{2}$ & $\begin{array}{c}\mathrm{Tb}_{3} \mathrm{Ge}_{5} \\
(P, 1653)\end{array}$ & & $\begin{array}{c}\mathrm{Ho}_{3} \mathrm{Ge}_{5} \\
(P, 1513)\end{array}$ & & & & \\
\hline & $\mathrm{Y}_{3} \mathrm{Ge}_{5}$ & $\begin{array}{c}\mathrm{Tb}_{3} \mathrm{Ge}_{5} \\
(T, 1163)\end{array}$ & $\begin{array}{c}\mathrm{Dy}_{3} \mathrm{Ge}_{5} \\
(P, 1208)\end{array}$ & $\begin{array}{c}\mathrm{Ho}_{3} \mathrm{Ge}_{5} \\
(T, 1213)\end{array}$ & & & & \\
\hline & $\mathrm{Th}_{3} \mathrm{Pd}_{5}$ & & & & & & $\begin{array}{c}\mathrm{Yb}_{3} \mathrm{Ge}_{5} \\
(P, 1348)\end{array}$ & \\
\hline \multirow{2}{*}{$\sim 0.5$} & $\mathrm{AlB}_{2}$ & $\begin{array}{c}\mathrm{TbGe}_{1.5} \\
(P, 1693)\end{array}$ & $\begin{array}{c}\mathrm{DyGe}_{1.5} \\
(P, 1676)\end{array}$ & $\begin{array}{c}\mathrm{HoGe}_{1.5} \\
(P, 1673)\end{array}$ & $\begin{array}{c}\mathrm{ErGe}_{1.5} \\
(P, 1678)\end{array}$ & & $\begin{array}{c}\mathrm{YbGe}_{1.5} \\
(L, 1353)\end{array}$ & $\begin{array}{c}\mathrm{LuGe}_{1.5} \\
(P, 1603)\end{array}$ \\
\hline & $\mathrm{Tm}_{2} \mathrm{Ge}_{3}$ & & & & & $\begin{array}{c}\mathrm{Tm}_{2} \mathrm{Ge}_{3} \\
(P, 1545)\end{array}$ & & \\
\hline
\end{tabular}




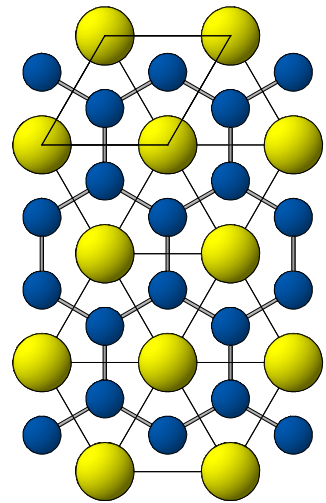

$\mathrm{AlB}_{2}$

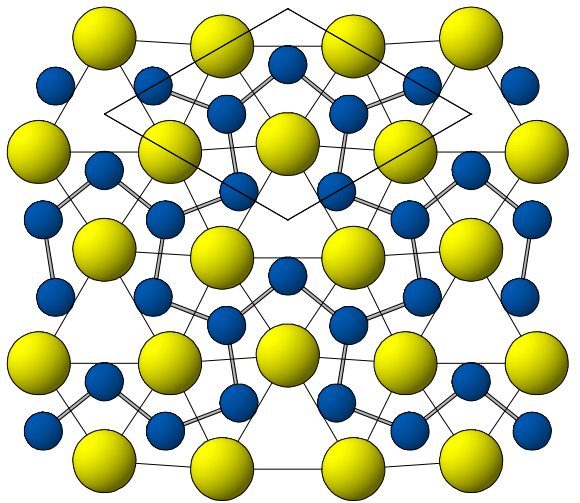

$\mathrm{Th}_{3} \mathrm{Pd}_{5}$

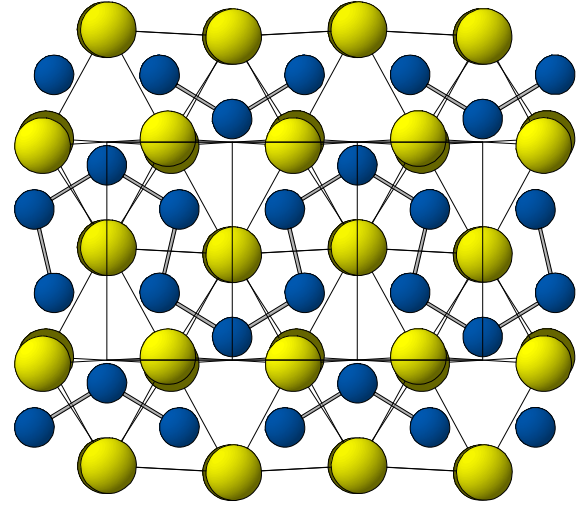

$\mathrm{Tm}_{2} \mathrm{Ge}_{3}$

Fig. 1 Structure type $\mathrm{AlB}_{2}$ and ordered vacancy derivatives.
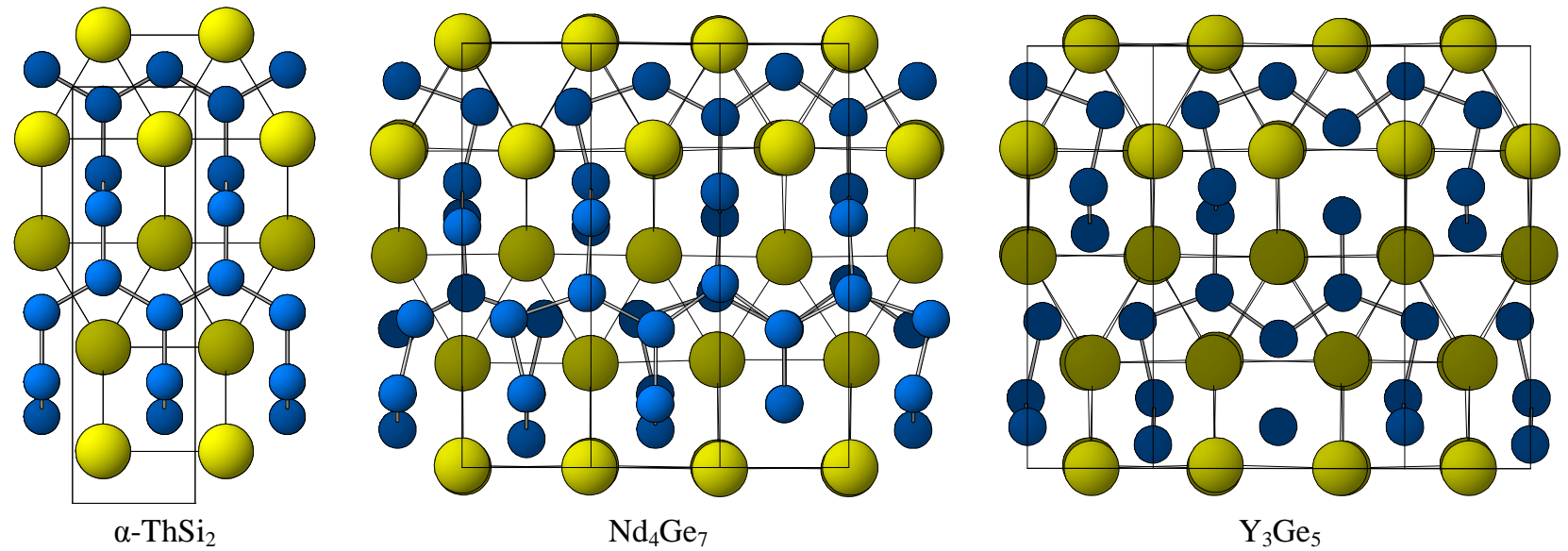

Fig. 2 Structure type $\alpha-\mathrm{ThSi}_{2}$ and ordered vacancy derivatives.

Table 3 Valence electron concentration per anion for $R \mathrm{Si}_{2-x}, R \mathrm{Ge}_{2-x}$, and $R(\mathrm{Ge}, \mathrm{Si})_{2-x}$ compounds with the structure types $\mathrm{AlB}_{2}, \alpha-\mathrm{ThSi}_{2}$ and derivatives $(\mathrm{AA}=$ average number of anion-anion bonds per anion, $\mathrm{VEC}_{\mathrm{A}}=$ valence electron concentration per anion).

\begin{tabular}{|c|c|c|c|c|}
\hline Composition & $R$, at. $\%$ & $x$ & $\mathrm{AA}$ & $\mathrm{VEC}_{\mathrm{A}}$ \\
\hline $\begin{array}{l}R^{3+} \mathrm{Si}_{1.5} \\
R^{3+} \mathrm{Ge}_{1.5}\left(R_{2} \mathrm{Ge}_{3}\right)\end{array}$ & 40.0 & 0.50 & 2 & 8 \\
\hline $\mathrm{Er}^{3+} \mathrm{Ge}_{0.82} \mathrm{Si}_{0.70}$ & 39.7 & 0.48 & 2.05 & 8.03 \\
\hline $\mathrm{Er}^{3+} \mathrm{Si}_{1.59}\left(\mathrm{Er}_{3} \mathrm{Si}_{4.76}\right)$ & 38.9 & 0.41 & 2.09 & 8.11 \\
\hline $\begin{array}{l}R^{3+} \mathrm{Si}_{1.67}\left(R_{3} \mathrm{Si}_{5}\right) \\
R^{3+} \mathrm{Ge}_{1.67}\left(R_{3} \mathrm{Ge}_{5}\right)\end{array}$ & 37.5 & 0.33 & 2.40 & 8.19 \\
\hline $\mathrm{Er}^{3+} \mathrm{Ge}_{1.00-0.73} \mathrm{Si}_{0.67-0.94}$ & 37.5 & 0.33 & 2.40 & 8.19 \\
\hline $\begin{array}{l}R^{3+} \mathrm{Si}_{1.75} \\
R^{3+} \mathrm{Ge}_{1.75}\left(R_{4} \mathrm{Ge}_{7}\right)\end{array}$ & 36.4 & 0.25 & 2.57 & 8.29 \\
\hline $\begin{array}{l}R^{3+} \mathrm{Si}_{2}{ }^{1}{ }^{1} \\
R^{3+} \mathrm{Ge}_{2}{ }^{1}\end{array}$ & 33.3 & 0 & 3 & 8.50 \\
\hline $\begin{array}{l}\mathrm{Eu}^{2+} \mathrm{Si}_{2} \\
\mathrm{Eu}^{2+} \mathrm{Ge}_{2}{ }^{2}\end{array}$ & 33.3 & 0 & 3 & 8 \\
\hline
\end{tabular}

${ }^{1}$ compounds reported with these compositions need to be confirmed; ${ }^{2}$ own structure type (space group $P-3 m 1$ ) [18], which is a deformation derivative of the $\mathrm{AlB}_{2}$ type 
Table 4 Valence electron concentration per anion for ternary compounds and solid solutions $R(\mathrm{Al}, \mathrm{Si})_{2-x}$, $R(\mathrm{Al}, \mathrm{Ge})_{2-x}$, and $R(\mathrm{Ga}, \mathrm{Ge})_{2-x}$ with the structure types $\mathrm{AlB}_{2}, \alpha-\mathrm{ThSi}_{2}$ and derivatives in the systems $\{\mathrm{Gd}, \mathrm{Er}\}-\{\mathrm{Al}, \mathrm{Ga}\}-(\mathrm{Si}, \mathrm{Ge}\}(\mathrm{C}=$ average number of valence electrons provided by each anion counting 3 for $\mathrm{Al}(\mathrm{Ga})$ and 4 for $\mathrm{Si}(\mathrm{Ge}), \mathrm{AA}=$ average number of anion-anion bonds per anion, $\mathrm{VEC}_{\mathrm{A}}=$ valence electron concentration per anion).

\begin{tabular}{l|c|c|c|c|c}
\hline \multicolumn{1}{c|}{ Composition } & $R$, at. $\%$ & $x$ & $\mathrm{C}$ & $\mathrm{AA}$ & $\mathrm{VEC}_{\mathrm{A}}$ \\
\hline $\mathrm{Gd}^{3+} \mathrm{Al}_{0.23} \mathrm{Si}_{1.33}{ }^{1}$ & 39.1 & 0.44 & 3.85 & 2.15 & 7.93 \\
\hline $\mathrm{Gd}^{3+} \mathrm{Al}_{0.26} \mathrm{Ge}_{1.28}$ & 39.4 & 0.46 & 3.88 & 2.10 & 7.93 \\
\hline $\mathrm{Er}^{3+} \mathrm{Ga}_{0.41-0.58} \mathrm{Si}_{1.21-1.11}$ & $38.2-37.2$ & $0.38-0.31$ & $3.75-3.66$ & $2.30-2.45$ & $7.90-7.88$ \\
\hline $\mathrm{Er}^{3+} \mathrm{Ga}_{0.13} \mathrm{Si}_{1.57}{ }^{1}$ & 37.1 & 0.30 & 3.92 & 2.47 & 8.16 \\
\hline $\mathrm{Er}^{3+} \mathrm{Al}_{0.14} \mathrm{Ge}_{1.57}$ & 36.9 & 0.29 & 3.92 & 2.49 & 8.17 \\
\hline $\mathrm{Gd}^{3+} \mathrm{Al}_{0.42} \mathrm{Ge}_{1.36}$ & 36.0 & 0.22 & 3.76 & 2.63 & 8.07 \\
\hline $\mathrm{Gd}^{3+} \mathrm{Al}_{0.89} \mathrm{Si}_{0.89}$ & 36.0 & 0.22 & 3.50 & 2.63 & 7.81 \\
\hline $\mathrm{Gd}^{3+} \mathrm{AlGe}^{3+}$ & 33.3 & 0 & 3.50 & 3 & 8 \\
\hline $\mathrm{Er}^{3+} \mathrm{Ga}_{1.48} \mathrm{Si}_{0.52}$ & 33.3 & 0 & 3.26 & 3 & 7.76 \\
\hline
\end{tabular}

${ }^{1}$ limiting composition of the substitutional / interstitial solid solution

In Table 4 the results of calculations for several rare-earth silicides and germanides containing aluminum or gallium are presented. The value of $\mathrm{VEC}_{\mathrm{A}}$ is in the range $7.8-8.2$, and at the equiatomic composition the compound $\mathrm{GdAlGe}$ (structure type $\alpha-\mathrm{ThSi}_{2}$ ) exhibits the characteristics of a polyanionic valence compound.

\section{Linear structure series with $\mathbf{A l B}_{2}$-type $\left(\alpha-\mathbf{T h S i}_{2}\right)$ segments}

In the binary $R-\mathrm{Ge}$ and ternary $R-\{\mathrm{Al}, \mathrm{Ga}\}-\mathrm{Ge}$ systems the compounds $R \mathrm{Ge}_{2-x}, R(\mathrm{Al}, \mathrm{Ge})_{2-x}$, and $R(\mathrm{Ga}, \mathrm{Ge})_{2-x}$ with $x<0.25$ crystallize in the structure types $\mathrm{ErGe}_{2.16}$ [19], $\mathrm{ZrSi}_{2}$ [20], $\mathrm{TbGe}_{2}$ [21], $\mathrm{PrGe}_{1.91}$ [22], TmGe ${ }_{1.9}$ [23], DyGe ${ }_{1.85}$ [24], and $\mathbf{Y G e}_{1.82}$ [25] (Table 5). These types belong to a linear inhomogeneous series of structures based on segments of the simple types hexagonal $\mathrm{AlB}_{2}$ (space group $P 6 / \mathrm{mmm})$ and cubic $\mathrm{CaF}_{2}(F m-3 m)$ [26]. The $\mathrm{AlB}_{2}$-type segments are layers of trigonal prisms $R_{6}$ centered by the smaller atoms, which have common bases and also share two of the three rectangular faces with neighboring prisms. The $\mathrm{CaF}_{2}$-type segments are double layers of empty tetragonal antiprisms formed by four $R$ atoms and four small atoms, the two layers having common atoms (small) and being related by a mirror or a glide plane [5].

In the orthorhombic structure types $\mathrm{TbGe}_{2}$ and $\mathrm{PrGe}_{1.91}$, blocks of three layers of trigonal prisms (arrangement of adjacent layers as in the type $\alpha-\mathrm{ThSi}_{2}$ ) are separated by a double layer characteristic of the type $\mathrm{CaF}_{2}$ (Fig. 3). The $\mathrm{PrGe}_{1.91}(\mathrm{Cmmm}$ ) type differs from the $\mathrm{TbGe}_{2}(\mathrm{Cmmm})$ type by a shift of most of the $\mathrm{Ge}$ atoms from their ideal positions, and the existence of disordered Ge vacancies in the central layer of the three-layer block of trigonal prisms.

The orthorhombic structure types $\mathrm{DyGe}_{1.85}$ $\left(C m c 2_{1}\right)$ and $\mathrm{YGe}_{1.82}(\mathrm{Cmcm})$ contain the same ratio (3:1) of $\mathrm{AlB}_{2^{-}}$and $\mathrm{CaF}_{2}$-type segments as the structures discussed above. However, the layers of trigonal prisms in these structures are fused as in the $\mathrm{AlB}_{2}$ type (all prism axes parallel). The two structure types differ in the displacements of the Ge atoms that center the prisms in the middle layer of the three-layer blocks of trigonal prisms.

The ratio of $\mathrm{AlB}_{2}$ - and $\mathrm{CaF}_{2}$-type segments in the orthorhombic structures of the $\mathrm{ErGe}_{2.16}$ and $\mathrm{ZrSi}_{2}$ types is $1: 1$. The $\mathrm{ErGe}_{2.16}(\mathrm{Cmcm})$ type is an example of insertion of additional small atoms into the $\mathrm{CaF}_{2}$-type segments (tetragonal antiprisms) of the $\mathrm{ZrSi}_{2}(\mathrm{Cmcm})$ type. In the closely related type $\mathrm{ZrGa}_{2}$ (Cmmm), two fused $\mathrm{CaF}_{2}$-type layers are related by a mirror plane. In the $\mathrm{TmGe}_{1.9}$ (Pmma) type, three-layer blocks of trigonal prisms and single layers of prisms alternate, separated by $\mathrm{CaF}_{2}$-type segments.

A linear inhomogeneous structure series based on segments of the simple types hexagonal $\mathrm{AlB}_{2}$ and cubic W $(I m-3 m)$ [27] (Fig. 3) is also known. The W-type segments are layers of empty $R_{4}$ tetrahedra that have common faces and edges [5]. In this series, the analogue of the structure type $\mathrm{YGe}_{1.82}$ is the orthorhombic type $\mathrm{V}_{2} \mathrm{~B}_{3}(\mathrm{Cmcm})$ [28], where the ratio of $\mathrm{AlB}_{2^{-}}$and $\mathrm{W}$-type segments is 3:1 and the $\mathrm{AlB}_{2}$-type layers contain prisms fused as in $\mathrm{AlB}_{2}$. It should be noted that this structure type is adopted by Si-deficient silicides $R_{2} \mathrm{Si}_{3-x}$, where $R$ is $\mathrm{Ce}, \mathrm{Pr}, \mathrm{Nd}$, $\mathrm{Tb}, \mathrm{Ho}, x=0-0.5$. The ternary orthorhombic types $\mathrm{Pr}_{4} \mathrm{Al}_{3} \mathrm{Ge}_{3}$ (Cmcm) [29] and $\mathrm{Er}_{4} \mathrm{Ga}_{2.72} \mathrm{Si}_{3.28}$ (C2 cm) [30] are analogues of the binary type $\mathrm{TbGe}_{2}$ (binary analogues are not known). The two structures are similar, but in $\mathrm{Er}_{4} \mathrm{Ga}_{2.72} \mathrm{Si}_{3.28}$ two of the five atom sites are split and the distribution of $p$-element atoms is different [30]. The structure of another ternary aluminum germanide, $\mathrm{Ba}_{3} \mathrm{Al}_{2} \mathrm{Ge}_{2}$ (Immm, superstructure of the type $\mathrm{Ta}_{3} \mathrm{~B}_{4}$ ) [31], adopted by $\mathrm{Eu}_{3} \mathrm{Al}_{1.8} \mathrm{Ge}_{2}$ [32], where Eu probably contributes two rather than three electrons, can be obtained by merging two $\mathrm{AlB}_{2}$-type segments and one $\mathrm{W}$-type segment. 

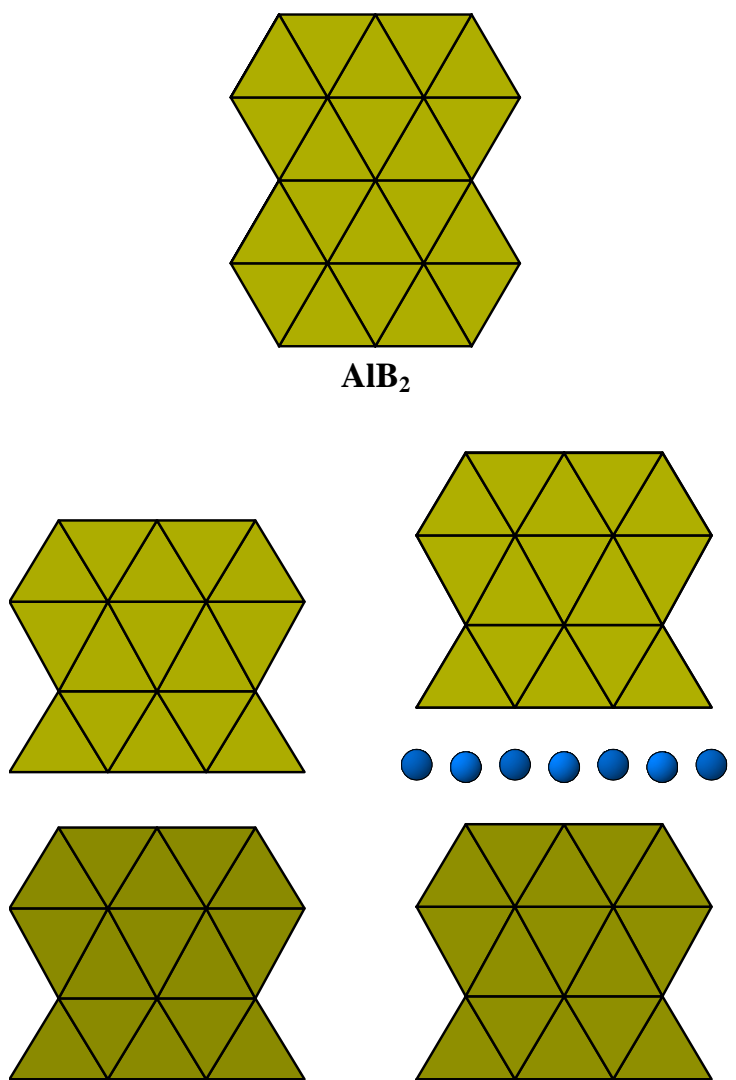

$\mathbf{V}_{2} \mathbf{B}_{3}$
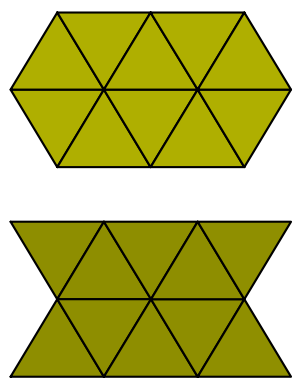

$\mathrm{Ba}_{3} \mathrm{Al}_{2} \mathrm{Ge}_{2}$

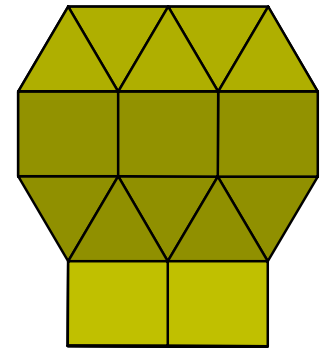

$\alpha-\mathbf{T h S i}_{2}$
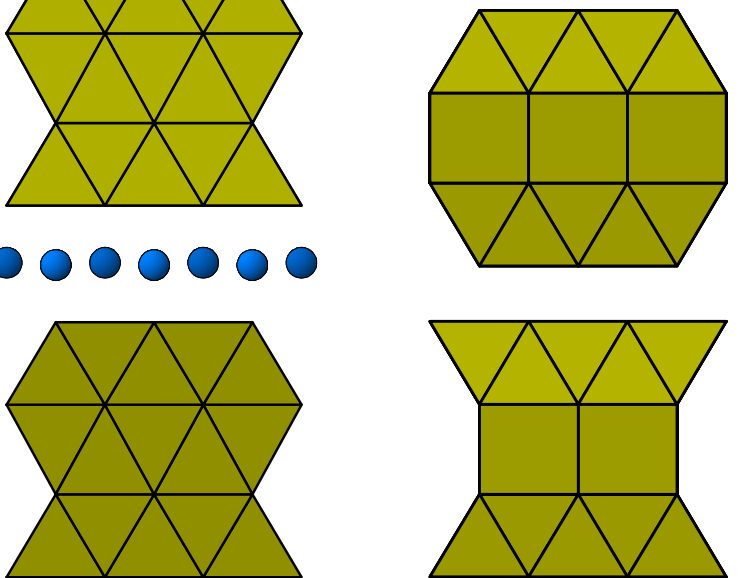

$\mathrm{YGe}_{1.82}$

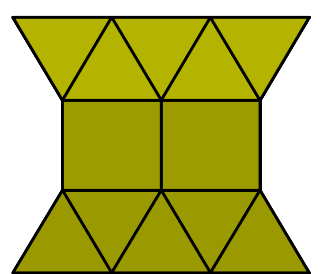

$\operatorname{Pr}_{4} \mathrm{Al}_{3} \mathrm{Ge}_{3}$

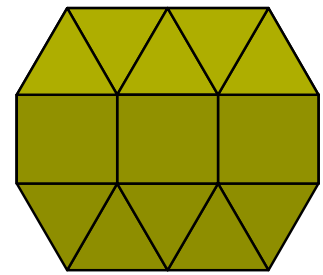

000000

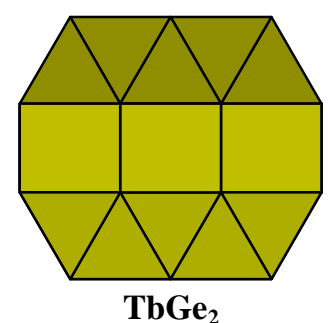

$\mathrm{TbGe}_{2}$
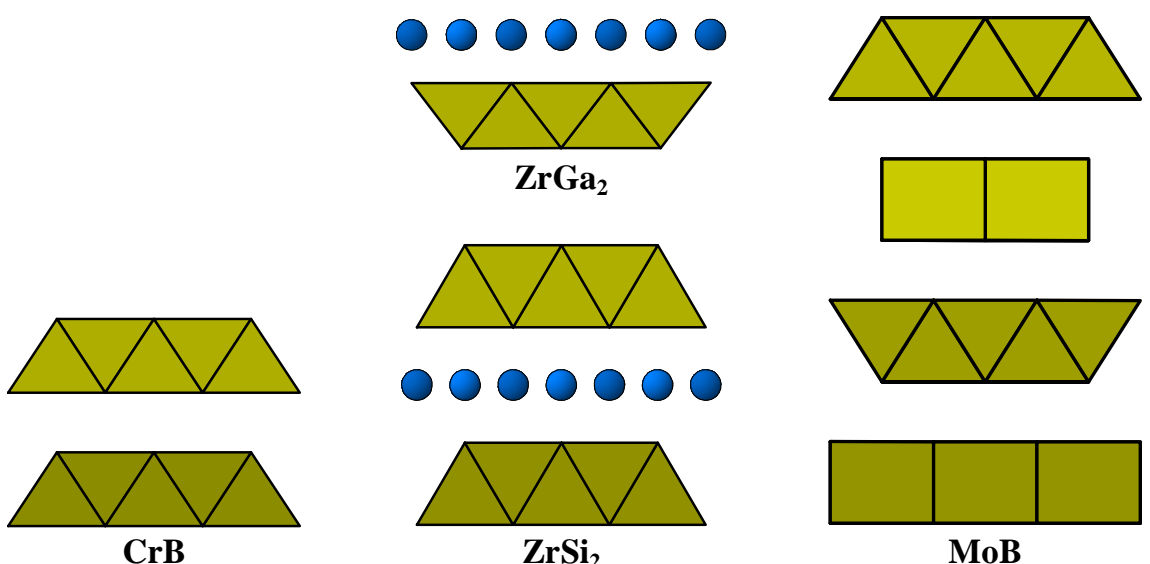

Fig. 3 Structure types belonging to the linear inhomogeneous structure series with $\mathrm{AlB}_{2^{-}}$and $\mathrm{W}$ - or $\mathrm{CaF}_{2}$-type segments. 
Table 5 Formation (filled fields) of compounds $R \mathrm{Ge}_{2-x}, R(\mathrm{Al}, \mathrm{Ge})_{2-x}$, and $R(\mathrm{Ga}, \mathrm{Ge})_{2-x}$ with intergrowth structures containing $\mathrm{AlB}_{2}$ - and $\mathrm{CaF}_{2}$-type segments.

\begin{tabular}{l|l|l|l|l|l|l|l|l|l|l|l|l|l|l|l}
\hline Structure type & $\mathrm{La}$ & $\mathrm{Ce}$ & $\mathrm{Pr}$ & $\mathrm{Nd}$ & $\mathrm{Sm}$ & $\mathrm{Eu}$ & $\mathrm{Gd}$ & $\mathrm{Tb}$ & $\mathrm{Dy}$ & $\mathrm{Ho}$ & $\mathrm{Er}$ & $\mathrm{Tm}$ & $\mathrm{Yb}$ & $\mathrm{Lu}$ \\
\hline $\mathrm{ErGe}_{2.16} / \mathrm{ZrSi}_{2}$ & & & & & & & & & \\
\hline
\end{tabular}

An analogue of the structure type $\mathrm{ZrSi}_{2}$ is the orthorhombic type TII $(\mathrm{Cmcm})$, often referred to as $\mathrm{CrB}$ for intermetallics [33]. Structures of this type are observed for rare-earth monosilicides and monogermanides. In the structure of the tetragonal type $\mathrm{MoB}\left(\mathrm{I}_{1} /\right.$ amd $)$ [34], as in $\mathrm{CrB}$ the ratio of $\mathrm{AlB}_{2^{-}}$ and $\mathrm{W}$-type segments is $1: 1$, but subsequent layers of trigonal prisms are rotated by $90^{\circ}$.

\section{Valence electron concentration for intergrowth structures}

Despite the lower number of vacancies in the compounds $\quad R \mathrm{Ge}_{2}, \quad R(\mathrm{Al}, \mathrm{Ge})_{2}, \quad$ and $\quad R(\mathrm{Ga}, \mathrm{Ge})_{2}$ $(x<0.25)$ with intergrowth structures built from $\mathrm{AlB}_{2^{-}}$ $\left(\alpha-\mathrm{ThSi}_{2}\right)$ and $\mathrm{CaF}_{2}$-type segments, in comparison with binary and ternary compounds with structures of the $\mathrm{AlB}_{2}, \alpha-\mathrm{ThSi}_{2}$ types or derivatives $(x=0.25-0.50)$, the valence electron concentration $\mathrm{VEC}_{\mathrm{A}}$ does not exceed 8.3 for the binary and 8.2 for the ternary compounds (see Table 6). For compounds with structures of the types $\mathrm{TbGe}_{2}\left(\mathrm{PrGe}_{1.91}\right)$ and $\mathrm{YGe}_{1.82}$ $\left(\mathrm{DyGe}_{1.85}\right)$ the average number of $\mathrm{A}-\mathrm{A}$ bonds per $\mathrm{Ge}$ atom can be calculated by the formula:

$$
\mathrm{AA}=\frac{22-17 \mathrm{x}}{\mathrm{x}^{2}-6 \mathrm{x}+8}
$$

Based on experimental data, we assume that defects occur at atom sites that center three-capped trigonal prisms (three homoatomic bonds for full occupation), and that the $\mathrm{Ge}$ atoms in the $\mathrm{CaF}_{2}$-type segments form three homoatomic bonds, which represents the average value for the two boundary cases - a square net and a zigzag chain. The number of valence electrons per anion for a binary rare-earth germanide $R \mathrm{Ge}_{2-x}$ is equal to:

$$
\mathrm{VEC}_{\mathrm{A}}=4+\frac{6}{4-\mathrm{x}}+\frac{22-17 \mathrm{x}}{\mathrm{x}^{2}-6 \mathrm{x}+8}
$$

which becomes, in the case of a ternary compound with aluminum (gallium):

$$
\begin{gathered}
\mathrm{VEC}_{\mathrm{A}}=\mathrm{C}+\frac{6}{4-\mathrm{x}}+\frac{22-17 \mathrm{x}}{\mathrm{x}^{2}-6 \mathrm{x}+8,} \\
\mathrm{C}=\frac{[\mathrm{Al}(\mathrm{Ga})] \times 3+[\mathrm{Ge}] \times 4}{[\mathrm{Al}(\mathrm{Ga})]+[\mathrm{Ge}]},
\end{gathered}
$$

where $[\mathrm{Al}(\mathrm{Ga})]$ and $[\mathrm{Ge}]$ is the number of $\mathrm{Al}(\mathrm{Ga})$ and Ge atoms, respectively, in the formula unit.

Table 6 Number of valence electrons per anion for $R \mathrm{Ge}_{2 \pm x}, R(\mathrm{Al}, \mathrm{Ge})_{2-x}$, and $R(\mathrm{Ga}, \mathrm{Ge})_{2-x}$ compounds with

\begin{tabular}{|c|c|c|c|c|c|c|}
\hline Composition & Structure type & $R$, at. $\%$ & $x$ & $\mathrm{C}$ & $\mathrm{AA}$ & $\mathrm{VEC}_{\mathrm{A}}$ \\
\hline $\mathrm{Er}^{3+} \mathrm{Ge}_{2.16}$ & $\mathrm{ErGe}_{2.16}$ & 31.6 & 0.16 & 4 & 2.91 & 8.30 \\
\hline $\mathrm{Gd}^{3+} \mathrm{Al}_{0.15} \mathrm{Ge}_{2.01}$ & $\mathrm{ErGe}_{2.16}$ & 31.6 & 0.16 & 3.93 & 2.91 & 8.23 \\
\hline $\mathrm{Er}^{3+} \mathrm{Al}_{0.15} \mathrm{Ge}_{1.92}$ & $\mathrm{ErGe}_{2.16}$ & 32.5 & 0.07 & 3.93 & 2.69 & 8.07 \\
\hline $\begin{array}{l}\mathrm{Er}^{3+} \mathrm{Al}_{0.15} \mathrm{Ge}_{1.85} \\
\mathrm{Er}^{3+} \mathrm{Ga}_{0.15} \mathrm{Ge}_{1.85}\end{array}$ & $\mathrm{ZrSi}_{2}$ & \multirow[t]{2}{*}{33.3} & \multirow[t]{2}{*}{0} & \multirow[t]{2}{*}{3.93} & 2.50 & 7.93 \\
\hline $\mathrm{Ho}^{3+} \mathrm{Ga}_{0.15} \mathrm{Ge}_{1.85}$ & $\operatorname{PrGe}_{1.91}$ & & & & 2.75 & 8.18 \\
\hline $\mathrm{Tb}^{3+} \mathrm{Ge}_{2}$ & $\mathrm{TbGe}_{2}$ & 33.3 & 0 & 4 & 2.75 & 8.25 \\
\hline $\operatorname{Pr}^{3+} \mathrm{Ge}_{1.91}$ & $\operatorname{PrGe}_{1.91}$ & 34.4 & 0.09 & 4 & 2.74 & 8.27 \\
\hline $\mathrm{Gd}^{3+} \mathrm{Ge}_{1.97}$ & $\operatorname{PrGe}_{1.91}$ & 33.7 & 0.03 & 4 & 2.75 & 8.26 \\
\hline $\mathrm{Dy}^{3+} \mathrm{Ge}_{1.85}$ & DyGe $_{1.85}$ & 35.1 & 0.15 & 4 & 2.73 & 8.29 \\
\hline $\mathrm{Y}^{3+} \mathrm{Ge}_{1.82}$ & $\mathrm{YGe}_{1.82}$ & 35.5 & 0.18 & 4 & 2.72 & 8.29 \\
\hline
\end{tabular}
intergrowth structures containing $\mathrm{AlB}_{2^{-}}\left(\alpha-\mathrm{ThSi}_{2}\right)$ and $\mathrm{CaF}_{2}$-type segments $(\mathrm{C}=$ average number of valence electrons provided by an anion, $\mathrm{AA}=$ average number of anion-anion bonds per anion, $\mathrm{VEC}_{\mathrm{A}}=$ valence electron concentration per anion). 
For a stoichiometric binary rare-earth germanide of the structure type $\mathrm{ZrSi}_{2}\left(R^{3+} \mathrm{Ge}_{2}\right) \mathrm{AA}=(3+2) / 2=$ 2.5 , and $\mathrm{VEC}_{\mathrm{A}}=4+3 / 2+2.5=8$. Larger values of $\mathrm{VEC}_{\mathrm{A}}$ are reached by inserting additional germanium atoms into voids of the structure, e.g. adopting the type $\mathrm{ErGe}_{2.16}$. The calculations were performed according to the following formulas:

$$
\begin{gathered}
\mathrm{AA}=\frac{5+8 \mathrm{x}}{2+\mathrm{x}}, \\
\mathrm{VEC}_{\mathrm{A}}=\mathrm{C}+\frac{3}{2+\mathrm{x}}+\frac{5+8 \mathrm{x}}{2+\mathrm{x}}=\mathrm{C}+\frac{8(1+\mathrm{x})}{2+\mathrm{x}} .
\end{gathered}
$$

The empirical limiting valence electron concentration per $p$-element atom, $\mathrm{VEC}_{\mathrm{A}}$ is 8.3 (binary compounds) and $\mathrm{VEC}_{\mathrm{A}} \leq 8.2$ (ternary compounds), is also observed for silicides with the structure type $\mathrm{V}_{2} \mathrm{~B}_{3}\left(\mathrm{VEC}_{\mathrm{A}}=8.18\right.$ for the composition $R_{2} \mathrm{Si}_{2.5}$ ) and the ternary compounds $\mathrm{Pr}_{4} \mathrm{Al}_{3} \mathrm{Ge}_{3}$ (8.17) and $\mathrm{Er}_{4} \mathrm{Ga}_{2.72} \mathrm{Si}_{3.28}$ (8.21). The limiting value of $\mathrm{VEC}_{\mathrm{A}} \approx 8.3$ is observed for $R^{3+} \mathrm{Ge}_{1.75}$ compounds $(x=0.25)$ with structure types $\mathrm{AlB}_{2}, \alpha-\mathrm{ThSi}_{2}$ or derivatives, $\mathrm{Y}^{3+} \mathrm{Ge}_{1.82}(x=0.18), \operatorname{Pr}^{3+} \mathrm{Ge}_{1.91}(x=0.09)$, and $\mathrm{Er}^{3+} \mathrm{Ge}_{2.16}(x=-0.16)$.

\section{Conclusions}

It is shown that the valence electron concentration is an essential criterion for the formation of rare-earth germanides (silicides) with the structure types $\mathrm{AlB}_{2}$, $\alpha-\mathrm{ThSi}_{2}$, or vacancy derivatives of these. The same observation was made for representatives of the series of structures based on $\mathrm{AlB}_{2-}$ and $\mathrm{CaF}_{2^{-}}$or $\mathrm{W}$-type slabs. For all these compounds, the maximum valence electron concentration per $p$-element atom $\left(\mathrm{VEC}_{\mathrm{A}}\right)$ is 8.3. The required value of $\mathrm{VEC}_{\mathrm{A}}$ is achieved by vacancies on the sites occupied by $\mathrm{Si}(\mathrm{Ge})$ atoms, different arrangements of structural segments, or heterovalent substitution of part of the $\mathrm{Si}$ or Ge atoms by $\mathrm{Al}$ or $\mathrm{Ga}$ atoms. For the ternary compounds, the highest empirical value observed for $\mathrm{VEC}_{\mathrm{A}}$ is 8.2.

\section{Acknowledgements}

This work was supported by the Ministry of Education and Science of Ukraine (grant No. 0118U003609).

\section{References}

[1] T.B. Massalski (Ed.), Binary Alloy Phase Diagrams, American Society for Metals, Materials Park, OH, USA, 1986, Vols. 1-4, 2224 p.

[2] H. Okamoto (Ed.), Desk Handbook: Phase Diagrams for Binary Alloys, American Society for Metals, Materials Park, OH, USA, 2000, $828 \mathrm{p}$.
[3] P. Villars, K. Cenzual, J.L.C. Daams, F. Hulliger, H. Okamoto, K. Osaki, A. Prince, S. Iwata (Eds.), Pauling File, Inorganic Materials Database and Design System, Binaries Edition, Crystal Impact (Distributor), Bonn, Germany, Release 2002/1.

[4] E.I. Gladyshevskii, Crystal Chemistry of Silicides and Germanides, Metallurgy, Moscow, 1971, 296 p. (in Ukrainian).

[5] E. Parthé, L. Gelato, B. Chabot, M. Penzo, K. Cenzual, R. Gladyshevskii, TYPIX. Standardized Data and Crystal Chemical Characterization of Inorganic Structure Types, Springer-Verlag, Berlin, Germany, 1993/1994, Vols. 1-4, 1596 p.

[6] E.J. Felten, J. Am. Chem. Soc. 78 (1956) 5977-5978.

[7] G. Brauer, A. Mitius, Z. Anorg. Allg. Chem. 249 (1942) 325-339.

[8] J.R. Thomson, Acta Crystallogr. 16 (1963) 320-321.

[9] G. Venturini, I. Ijjaali, B. Malaman, J. Alloys Compd. 284 (1999) 262-269.

[10] V. Ghetta, E. Hoossay, A. Rouault, R. Madar, B. Lambert, C. R. Acad. Sci., Ser. II 309 (1989) 995-1000.

[11] S. Pukas, L. Akselrud, R. Cerny, R. Gladyshevskii, Chem. Met. Alloys 1 (2008) 185-191 (in Ukrainian).

[12] G. Venturini, I. Ijjaali, B. Malaman, J. Alloys Compd. 289 (1999) 168-177.

[13] G. Venturini, I. Ijjaali, B. Malaman, J. Alloys Compd. 285 (1999) 194-203.

[14] B. Lambert, E. Houssay, R. Madar, F. Hippert, J. Pierre, S.Auffret, J. Less-Common Met. 167 (1990) 53-63.

[15] J.A. Perri, I. Binder, B. Post, J. Phys. Chem. 63 (1959) 616-619.

[16] S. Pukas, Thesis, Ivan Franko National University of Lviv, 2008.

[17] E. Parthé, Elements of Inorganic Structural Chemistry, K. Sutter Publisher, Petit-Lancy, Switzerland, 1990, 158 p.; Елементи неорганічної структурної хімії, Світ, Lviv, 1993, 104 p. (in Ukrainian).

[18] E.I. Gladyshevskii, Zh. Strukt. Khim. 5 (1964) 568-575 (in Russian).

[19] G. Venturini, I. Ijjaali, B. Malaman, J. Alloys Compd. 288 (1999) 183-187.

[20] S.V. Naray Szabo, Z. Kristallogr. 97 (1937) 223-228.

[21] P. Schobinger Papamantellos, D.B. De Mooij, K.H.J. Buschow, J. Less-Common Met. 144 (1988) 265-274.

[22] I. Savysyuk, N. Semuso, R. Gladyshevskii, Chem. Met. Alloys 10 (2017) 45-97.

[23] G. Venturini, J. Alloys Compd. 308 (2000) 200-204.

[24] I.R. Mokra, V.K. Pecharskii, Z.M. Shpyrka, O.I. Bodak, V.K. Belskii, I.E. Patz, Dopov. Akad. Nauk Ukr. RSR, Ser. B 3 (1989) $45-47$ (in Ukrainian). 
[25] I. Ijjaali, G. Venturini, B. Malaman, J. Alloys Compd. 284 (1999) 237-242.

[26] W.L. Bragg, Proc. R. Soc. London, Ser. A 89 (1914) 468-489.

[27] P. Debye, Phys. Z. 18 (1917) 483-488.

[28] Y. Yu, L.E. Tergenius, T. Lundström, S. Okada, J. Alloys Compd. 221 (1995) 86-90.

[29] E.I. Gladyshevskii, N.Z. Semuso, R.E. Gladyshevskii, K. Cenzual, J.L. Jorda, Chem. Met. Alloys 1 (2008) 352-359.
[30] S.Ya. Pukas, R. Cerny, M.B. Manyako, R.E. Gladyshevskii, Ukr. Khim. Zh. 73(11) (2007) 18-26 (in Ukrainian).

[31] A. Widera, B. Eisenmann, H. Schäfer, K. Turban, Z. Naturforsch. B 31 (1976) 1592-1595.

[32] B. Bauer, C. Röhr, Z. Naturforsch. B 66 (2011) 793-812.

[33] F. Bertaut, P. Blum, Acta Crystallogr. 4 (1951) 66-67.

[34] R. Kiessling, Acta Chem. Scand. 1 (1947) 893-916. 